\title{
ВПРОВАДЖЕННЯ ВІЙСЬКОВО-МЕДИЧНИХ ДИСЦИПЛІН У ПІДГОТОВКУ ФЕЛЬДШЕРІВ ТА МЕДИЧНИХ СЕСТЕР
}

\author{
О. М. Ляшок, С. О. Бондарь, О. Б. Варава \\ Кіровоградський базовий медичний коледж ім.. Й. Мухіна
}

У статті розглянуто шляхи модернізації військово-медичної підготовки у медичних коледжах та питання оптимізації навчання майбутніх медиків невідкладній допомозі в екстремальних умовах зони АТО.

\section{INTRODUCTION OF MILITARY-MEDICAL DISCIPLINES TO THE TRAINING OF PARAMEDICS AND MEDICAL NURSES}

\author{
O. M. Lyashok, S. O. Bondar, O. B. Varava \\ Kirovohrad Medical College by Ye. Y. Mukhin
}

The article discusses the ways of modernization of military-medical training in medical colleges and the questions of optimizing teaching of the future medical workers how to render first aid in extreme conditions of the ATO zone.

Вступ. Воєнна ситуація на сході нашої держави, застосування в зоні АТО нових методів ведення бойових дій оголили безліч проблем, у тому числі й проблеми «боєздатності» вітчизняної медицини. Вона вже давно почала забувати, що таке військово-польова хірургія, а про лікування уражень від сучасної зброї годі й говорити. Згідно з даними бюро судмедекспертизи, близько 16 \% наших героїв загинули внаслідок несумісних з життям травм головного мозку, майже $11 \%$ - від несумісних з життям політравм внаслідок вибуху, близько 3 \% - від поранень шиї і спинного мозку, приблизно 5 \% - від крововтрати, 25 \% - від поранень тулуба і внутрішніх органів з кровотечами, 40 \% - від поранення кінцівок. Зрозуміло, що більшість ушкоджень і поранень становить хірургічна патологія. Найбільше навантаження лягає на такий розділ, як військово-польова хірургія. Актуальними також $\epsilon$ питання надання терапевтичної, неврологічної та психологічної допомоги [1, 2].

Одним із нагальних завдань $є$ більш активне і вдумливе впровадження військово-медичних дисциплін у підготовку молодших медичних спеціалістів. Першим кроком на цьому шляху є створення державної військово-медичної доктрини, запропонованої авторським колективом під керівництвом Ольги Богомолець. Документ пропонує багатоаспектне вирішення

(ㄱ О. М. Ляшок, С. О. Бондарь, О. Б. Варава, 2015 проблеми - від відновлення уроку охорони життя в школі до набуття у ВМНЗ навичок військово-польової медицини та санітарної гігієни при зараженні навколишнього середовища [5].

Відповідно до навчальних планів спеціальностей «Лікувальна справа», «Акушерська справа», «Сестринська справа», «Медико-профілактична справа» викладаються дисципліни «Військово-медична підготовка та медицина надзвичайних ситуацій» і «Безпека життєдіяльності». Майбутні фельдшери і медсестри, які навчаються на базі основної школи, опановують ще й «Захист Вітчизни». Тож потреби у введенні до навчальних планів додаткових військово-медичних дисциплін немає. Проте необхідно удосконалити навчальні програми запропонованих дисциплін.

Основна частина. Наше бачення шляхів удосконалення підготовки майбутніх медичних фахівців 3 питань надання невідкладної медичної допомоги в екстремальних умовах базується на кількох засадах. Чи не головна з них - увага до практичного тренінгу майбутніх фельдшерів і медичних сестер, відпрацювання під час занять етапів роботи в екстремальних умовах, коли обсяг діагностичних і лікувальних заходів різко обмежений. Під час лекційних курсів обов'язковими для висвітлення мають стати питання медичного сортування за нозологічним принципом, інформація про сучасні види зброї, що застосовують у зоні АТО, з'ясування структури санітарних втрат, 
способів та особливостей лікувально-евакуаційного забезпечення у зоні АТО, наближення надання кваліфікованої медичної допомоги до поранених [3, 4].

На практичних заняттях особливу увагу слід приділяти відпрацюванню послідовності лікування постраждалих на етапах медичної евакуації. Враховуючи природний процес «вимивання» знань, надалі студенти повинні закріплювати означенні вміння під час виробничої практики. Ряд практичних умінь і навичок можна відпрацьовувати у два етапи. На першому етапі студенти засвоюють техніку виконання маніпуляцій на тренажерах, фантомах і муляжах, наприклад, введення повітроводу, штучне дихання, непрямий масаж серця, пункції суглобів та інших порожнин. На другому етапі майбутні фахівці можуть вдосконалювати окремі навички один на одному, наприклад, накладати джгут, застосовувати транспортну іммобілізацію, відпрацьовувати десмургію тощо. Уміння і навички мають бути доведені до автоматизму. 3 цією метою доцільно, на наш погляд, використовувати методику поглибленого клінічного обстеження хворих із політравмою, що дає змогу протягом кількох хвилин виявити локалізацію ушкодження, особливо домінуючого, відновити прохідність дихальних шляхів і зупинити кровотечу, накласти герметичну, асептичну та протиопікову пов'язки, застосовувати засоби транспортної іммобілізації. Частина цих навичок формується протягом всього періоду навчання під час вивчення близьких за змістом дисциплін: реанімації, хірургії, невідкладних станів у фельдшерів та медсестринства в хірургії у медичних сестер.

Доцільно було 6 створити кабінети міждисциплінарної практики, які 6 відтворювали умови для відпрацювання навичок медичної евакуації на різних етапах. Проте оптимальною методикою набуття навичок залишається добре спланована і організована викладачем самостійна робота студентів з ургентними хворими, чергування у приймально-діагностичному, травматологічному та інших хірургічних відділеннях, а також у реанімаційному залі. Протягом навчання необхідно підкреслювати чітку залежність між шансом на виживання і часом надання медичної допомоги постраждалим, особливо на догоспітальному етапі, який, по суті, $є$ «рукою клініки в зоні катастрофи». Нагальним питанням підготовки студентів до надання допомоги постраждалим у зоні катастрофи, на наш погляд, мають стати уніфікація програми та технологія розробки стандартизованих схем надання долікарської допомоги в екстремальних умовах.
Питання військово-польової хірургії мають бути включені до програми державного іспиту: у вигляді тестового контролю, перевірки практичних навичок та співбесіди.

Одним із аспектів викладання ВМП на спеціальності «Медико-профілактична справа» $\epsilon$ необхідність внесення змін до організації санітарно-гігієнічного та протиепідемічного забезпечення у зоні АТО, зосередження на питаннях гігієни водопостачання, харчування та розташування військ. У підготовці фармацевтів доцільно було б звернути увагу на питання забезпечення лікувальними засобами, комплектації індивідуальних аптечок і аптечок групового забезпечення. Вони могли б стати навчальною метою при викладанні «Безпеки життєдіяльності» та «Першої долікарської допомоги».

Для постраждалих у зоні АТО вкрай потрібні психологи та психіатри. Набуття цих аспектів підготовки можливе під час вивчення дисциплін «Основ загальної та медичної психології» та «Психіатрія і наркологія».

У підготовці фахівців можна умовно виокремити три етапи: професійна орієнтація, практичний тренінг під керівництвом викладача, застосування навичок у самостійній практичній діяльності. У коледжі налагоджено систему відпрацювання навичок з військово-медичної підготовки поза межами навчального процесу. У жовтні 2014 року спільно з обласним територіально-медичним об'єднанням «Центр екстреної медичної допомоги та медицини катастроф» студенти-випускники сестринського і фельдшерського відділень брали участь у військовомедичних тренуваннях. Метою цього заходу було практичне відпрацювання дій цивільного захисту населення і територій в надзвичайних ситуаціях, надання допомоги постраждалим на різних етапах проведення рятувальних робіт.

Питанням надання екстреної медичної допомоги постраждалим під час бойових дій та в осередках надзвичайних ситуацій у нашому навчальному закладі приділяється увага вже понад півтора десятиліття. Творчим колективом викладачів військово-медичних дисциплін видано у різних видавництвах України більше десяти підручників, практикумів та навчальних посібників. У них розкрито питання організації медичного забезпечення військ і медичного постачання $з$ урахуванням сучасних досягнень військово-медичної науки, військово-польової терапії та хірургії, особливостей надання допомоги дітям у надзвичайних ситуаціях, військової гігієни та епідеміології. У цих виданнях 
подано тести, задачі та завдання для самопідготовки студентів, а також для контролю рівня набутих знань, практичних навичок і вмінь з кожної теми, запропоновано інструкції та алгоритми роботи студентів на практичних заняттях. Тепер ця навчальна література потребує удосконалення та доповнень, продиктованих сучасними реаліями та перебігом АТО.

Коледж долучився й до проведення медиковолонтерських навчань. Їх мета - навчити цивільне населення надавати долікарську допомогу постраждалим у разі здійснення терористичного акту на території України.

У зоні АТО велика потреба у парамедиках. Тому на звернення громадської організації «Народна самооборона - Кіровоград» викладачами коледжу в позанавчальний час на безоплатній основі проводять курси для цивільного населення з надання домедичної допомоги постраждалим у надзвичайних ситуаціях. Курси передбачають оволодіння навичками евакуації поранених, зупинки кровотечі, іммобілізації ушкоджених кінцівок, штучної вентиляції легень, непрямого масажу серця, допомоги при втраті свідомості.

Для поліпшення медичного забезпечення у зоні АТО коледж силами викладачів-клініцистів та фахівців практичної охорони здоров'я обласного рівня на безоплатній основі здійснює підготовку вчителів середніх загальноосвітніх навчальних закладів за програмою санітарних інструкторів військово-медичної підготовки. Для цього на відділенні післядипломної освіти розроблено програму навчання обсягом 40 годин, яка розрахована на слухачів без базової медичної освіти.

\section{ЛІТЕРАТУРА}

1. Андронатій В. Медики на війні - як забезпечити готовність «номер один»? / В. Андронатій // Ваше здоров'я. 2014. - 5 вересня. - С. 6-7.

2. Левицький П. 90 \% поранених гинуть ще на полі бою / П. Левицький // Ваше здоров'я. - 2015. - 20 березня. С. 6-7.

3. Провалов А. Медичні будні в зоні АТО / А. Провалов // Ваше здоров'я. - 2014. - 3 жовтня - С. 15.
На першому етапі планують підготувати вчителів 3 предмета «Захист Вітчизни».

У жовтні цього року на базі коледжу проведено навчально-тренувальний семінар для викладачів області, на якому розглядали проблеми надання домедичної допомоги при надзвичайних ситуаціях, вивчали досвід фахівців, які побували у зоні АТО, Афганістані та в інших «гарячих точках світу».

Викладачі Кіровоградського медичного коледжу прагнуть не тільки навчити особливостям надання кваліфікованої допомоги, а й виховати патріота своєї Вітчизни. Спільно з Департаментом освіти Кіровоградської міської ради, починаючи з цього навчального року викладачі-клініцисти коледжу викладають предмет «Захист Вітчизни» учням 10-11 класів загальноосвітніх шкіл м. Кіровограда.

У коледжі значно розвинувся волонтерський рух допомоги військовослужбовцям у зоні АТО. Для бійців 39 Кіровоградського батальйону, що надлюдською ціною утримував під контролем Донецький аеропорт, студенти здали понад 10 літрів резус-негативної крові. Колективом також було придбано 50 ковдр, медикаменти, продукти харчування та засоби гігієни.

Висновки. Питання розширення та осучаснення військово-медичної підготовки фельдшерів та медичних сестер сьогодні є одним із нагальних аспектів вдосконалення роботи медичних навчальних закладів. Сьогодні медики України разом зі своїм народом і державою складають чи не найскладніший екзамен на свою професійну компетентність, здатність до швидких змін та людську гідність. І, напевно, оцінюватись він буде кількістю врятованих молодих життів.

4. Романюк Д. Порятунок пораненого - справа рук самого пораненого? / Д. Романюк // Ваше здоров'я. - 2015. 3 квітня. - С. 16-17.

5. Супрун У. Без тактичної медицини не існує медицини військової / У. Супрун // Ваше здоров'я. - 2015. 6 лютого - С. 16-17.

6. Царенко Л. Психологи рятують бійців у зоні АТО / Л. Царенко // Ваше здоров'я. - 2014. - 3 жовтня. - С. 13. 